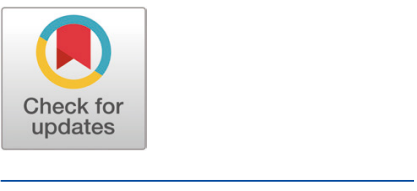

Received: Oct 21, 2019

Revised: Nov 12, 2019

Accepted: Nov 19, 2019

*Corresponding author Kyu-Hyun Park

College of Animal Life Sciences, Kangwon National University,

Chuncheon 24341, Korea.

Tel: +82-33-250-8621

E-mail: kpark74@kangwon.ac.kr

Copyright $\odot 2020$ Korean Society of Animal Sciences and Technology.

This is an Open Access article distributed under the terms of the Creative Commons Attribution Non-Commercial License (http:// creativecommons.org/licenses/by$\mathrm{nc} / 4.0 /$ ) which permits unrestricted non-commercial use, distribution, and reproduction in any medium, provided the original work is properly cited.

ORCID

Geun Woo Park

https://orcid.org/0000-0003-0336-4080 Ji Yung Kim

https://orcid.org/0000-0003-3515-1178

Min Hyeok Lee

https://orcid.org/0000-0001-5037-5343 Jung Im Yun

https://orcid.org/0000-0001-9633-2947

Kyu Hyun Park

https://orcid.org/0000-0002-6390-5478

Competing interests

No potential conflict of interest relevant to this article was reported.

Funding sources

This work was conducted with the

\section{Comparing greenhouse gas emissions and nutritional values based on Korean suggested meal plans and modified vegan meal plans}

\author{
Geun-woo Park ${ }^{1}$, Ji-yung Kim ${ }^{1}$, Min Hyeok Lee ${ }^{2}$, Jung-Im Yun ${ }^{1}$ \\ and Kyu-Hyun Park ${ }^{1 *}$ \\ ${ }^{1}$ College of Animal Life Sciences, Kangwon National University, Chuncheon 24341, Korea \\ ${ }^{2}$ Korea Institute of Industrial Technology, Gangnam-gu, Seoul 06211, Korea
}

\section{Abstract}

Producing animal products from farm to table emits massive amounts of greenhouse gases (GHGs). Modified meal plans, mainly including vegetables and grains, have been recommended to reduce GHG emissions. However, these meal plans have not been developed with regard to the micronutrient content, but rather with regard to the energy requirements of grains and vegetables, which could result in a nutritional imbalance. For this reason, we investigated a common Korean suggested meal plan (SMP) from the National Institute of Agricultural Sciences, in which nutritional conditions were considered, and evaluated its GHG emissions using the Life Cycle Assessment Inventory Database and nutritional values. The SMP, which included meat, was based on the Korean Nutrition Society for adult men age 19 to 29 , and was changed to a vegan meal plan (VMP). Animal-based protein sources were substituted for meat alternatives, such as beans and tofu, for which carbon footprint data was available. To compare the nutritional differences, the $9^{\text {th }}$ Korean Food Composition Tables I and II were consulted. To calculate GHG emissions, the carbon footprint data of the food was converted to a $\mathrm{CO}_{2}$ equivalent $\left(\mathrm{CO}_{2} \mathrm{e}\right)$ using a procedure from the Foundation of Agriculture Technology Commercialization and Transfer. It was found that GHG emissions per calorie were $18 \%$ lower for the VMP when compared to the SMP. However, if GHG emissions per total amino acids were evaluated, the VMP GHG emissions per total amino acids were $0.12 \mathrm{~g}$ $\mathrm{CO}_{2} \mathrm{e} / \mathrm{mg}$, while the corresponding value for the SMP was $0.06 \mathrm{~g} \mathrm{CO}_{2} \mathrm{e} / \mathrm{mg}$. The Korean daily meat intake reported by the Korea Agricultural Statistics Service was $37.1 \%$ lower than in the SMP, but when converted to a protein intake the figure was $17.0 \%$ lower. It was found that each SMP resulted in more GHG emissions than the VMP, but when considered as GHG emissions per total amino acids, the opposite pattern was apparent. There is a need to conduct more detailed studies of the variation in GHG emissions with different meal plans, using the daily meat intake per person.

Keywords: Amino acid, GHG emissions per amino acids, GHG emissions per protein, Meat diet, Micronutrient, Protein 
support of the Cooperative Research Program for Agriculture Science \& Technology Development (Project No. PJ01359001), Rural Development Administration, Korea.

Acknowledgements

This work was supported by the laboratory of atmospheric environmental science with livestock members and the professor Kyuhyun Park and others in department of animal life sciences in Kangwon national university and $\mathrm{PhD}$. Min hyeok Lee from Korea Institute of Industrial Technology.

Availability of data and material Please contact author for data requests.

Authors' contributions Conceptualization: Park GW, Park KH.

Data curation: Park GW.

Formal analysis: Park GW.

Methodology: Park GW, Kim JY.

Validation: Kim JY, Lee MH, Yun JI, Park KH.

Investigation: Park GW, Kim JY.

Writing - original draft: Park GW.

Writing - review \& editing: Kim JY, Lee MH, Yun JI, Park KH .

Ethics approval and consent to participate This article does not require IRB/IACUC approval because there are no human and animal participants.

\section{INTRODUCTION}

As incomes have risen and the population has become increasingly urbanized, diets and meal plans have changed, with an increased consumption of processed foods and meat. This transition of dietary habits has affected human health and the environment [1]. To maintain a sustainable environment and overall health, there has been a move toward eco-friendly food and some individuals have refrained from consuming animal-based foods [2]. As a result, vegan diets that contain no animal-based items have been increasing in popularity [2]. Many vegans have made nutritional choices with the aim of taking better care of the global environment, animal welfare, and the health advantages of a plant-based diet [3]. The production of food items from an animal source is associated with higher greenhouse gas (GHG) emissions than the production of plant-based food items because energy is lost at each trophic level [4,5]. When considering global GHG emissions by economic sector, the Agriculture, Forestry and Other Land Use sector accounts for $24 \%$ of the total [6]. According to the Food and Agriculture Organization of the United Nations (FAO), livestock contribute to nearly two-thirds of agricultural GHG emissions and 78\% of agricultural methane emissions. Using the Global Livestock Environmental Assessment Model (GLEAM), emissions from feed crops account for approximately $45 \%$ of the total emissions from livestock, and methane and nitrous oxide from manure account for approximately 10\% of total GHG emissions [7].

In this study, we used a common suggested meal plan SMP based on a Korean food menu and a vegan meal plan (VMP), which represented the SMP with all animal products substituted for alternatives. In Fig. 1 using these meal plans, the GHG emissions per kcal, GHG emissions per protein, and GHG emissions per amino acid were compared. We also considered the nutritional value of the SMP and VMP.

The amount of GHG emissions can be converted to a $\mathrm{CO}_{2}$ equivalent $\left(\mathrm{CO}_{2} \mathrm{e}\right)$ in food, largely based on the energy content $(\mathrm{MJ})$ of the products or the functional unit; i.e., $1 \mathrm{~kg}$ for most products [8]. However, meat or animal products are consumed because they are nutrient dense rather than for providing energy, and they typically contain proteins with all amino acids and micronutrients, such as iron $(\mathrm{Fe})$, zinc $(\mathrm{Zn})$, selenium $(\mathrm{Se})$, vitamin $\mathrm{D}$, and vitamin $\mathrm{B}_{12}$ [9-11]. Some studies con-

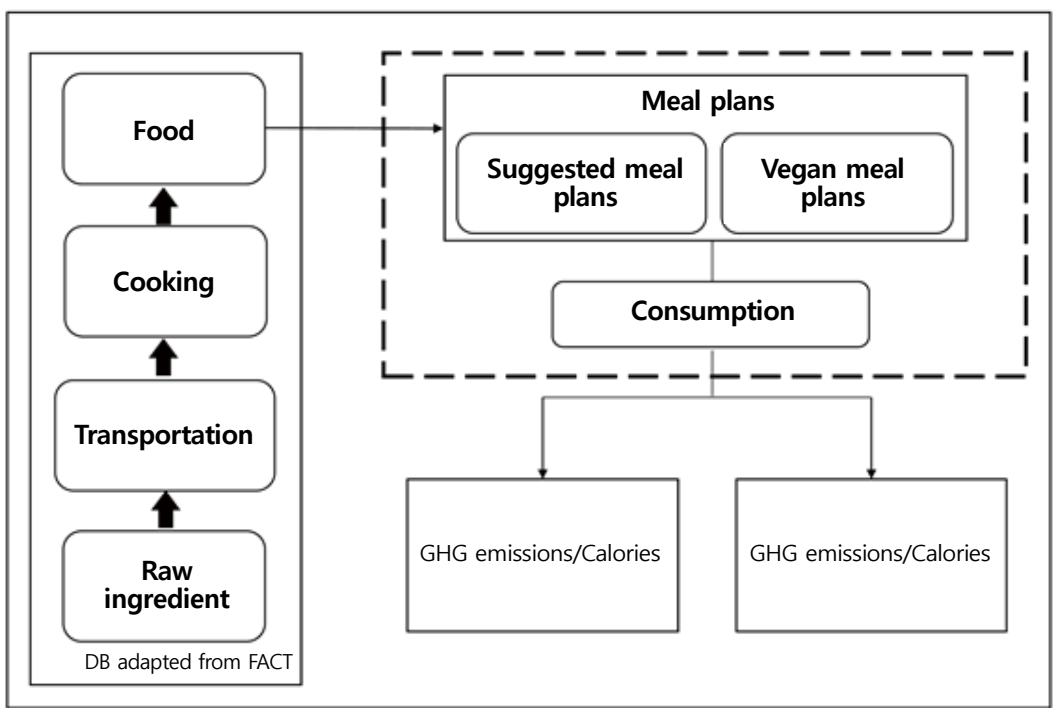

Fig. 1. System boundary for the meal plans to apply the GHGs emissions to the calories and nutrients. GHG, greenhouse gas. 
sider the GHG emissions related to foods, but they didn't consider GHG emissions with their nutrients and nutritional values $[5,12,13]$. It is therefore irrational to evaluate GHG emissions from meat on the basis of energy provided ( $\mathrm{kcal}$ ) rather than the amounts of protein or other micronutrients $(\mathrm{g}$ or $\mu \mathrm{g})$. Functional units, such as $\mathrm{GHG}$ emissions $\left(\mathrm{g} \mathrm{CO}_{2} \mathrm{e}\right)$ per protein $(\mathrm{g})$, GHG emissions ( $\mathrm{g}$ $\left.\mathrm{CO}_{2} \mathrm{e}\right)$ per amino acid $(\mathrm{mg})$, and $\mathrm{GHG}$ emissions $\left(\mathrm{g} \mathrm{CO}_{2} \mathrm{e}\right)$ per vitamin $\mathrm{B}_{12}(\mu \mathrm{g})$, are rarely considered $[10,11]$.

\section{MATERIALS AND METHODS}

\section{Study subjects and research methods}

The subjects of the study were adult men, over the age of 19, who had entered the post-high school stage of education, because their nutritional requirements were higher than other ages and genders [14]. Table 1 shows the content of the meal plans prepared according to the one day meal plan of the National Institute of Agricultural Sciences meal plan menu [14,15]. In the meal plan database, the age range is set from 19 to 29. The meal plan menu was divided into two categories: (1) the SMP, including animal products, such as meat and eggs, and (2) the VMP, which was based on the SMP, but animal-based protein sources, such as beans and tofu, were substituted for meat alternatives. To ensure the nutrient adequacy of each meal plan, the nutrient content was assessed against the $9^{\text {th }}$ Korean Food Composition Tables I and II published by the National Academy of Agricultural Science under the Rural Development Administration (RDA) [14-17].

Carbohydrates and proteins were selected as macronutrients, but fats were not considered because they were not included in the recommended intake. Proteins were subdivided into total amino acids, essential amino acids, and non-essential amino acids. To compare the macronutrients, the recommended intake was obtained from the 'Dietary Reference Intakes For Koreans 2015' (DRI 2015 ) to determine a standard value [14]. According to DRI 2015, the estimated energy required for adult men aged $19-29$ is 2,600 kcal/day, with carbohydrates accounting for $55 \%$ of the total food intake, and the suggested intake for proteins is $65 \mathrm{~g} /$ day. Although the recommended intakes of various amino acids are available in the DRI 2015, in the ${ }^{\text {th }}$ Korean Food Composition Tables I

Table 1. A comparison of the food intake, calories, and greenhouse gas (GHG) emissions between the vegan meal plan (VMP) and suggested meal plan (SMP) diets

\begin{tabular}{|c|c|c|c|c|c|c|c|c|}
\hline & \multicolumn{4}{|l|}{ VMP } & \multicolumn{4}{|c|}{ SMP } \\
\hline & $\begin{array}{l}\text { Menu } \\
(\mathrm{g})\end{array}$ & $\begin{array}{c}\text { Intake } \\
\text { (g) }\end{array}$ & $\begin{array}{c}\text { Calories } \\
\text { (kcal) }\end{array}$ & $\begin{array}{c}\text { GHG } \\
\text { emissions } \\
\left(\mathrm{g} \mathrm{CO}_{2} \mathrm{e}\right)\end{array}$ & $\begin{array}{c}\text { Menu } \\
(\mathbf{g})\end{array}$ & $\begin{array}{c}\text { Intake } \\
\text { (g) }\end{array}$ & $\begin{array}{c}\text { Calories } \\
\text { (kcal) }\end{array}$ & $\begin{array}{c}\text { GHG } \\
\text { emissions } \\
\left(\mathrm{g} \mathrm{CO}_{2} \mathrm{e}\right)\end{array}$ \\
\hline Breakfast & $\begin{array}{l}\text { Rice }(210 \mathrm{~g}) \\
\text { Potatoes seaweed soup }(52 \mathrm{~g}) \\
\text { Kimchi }(40 \mathrm{~g}) \\
\text { Seasoned spinach }(86 \mathrm{~g}) \\
\text { Braised black bean }(20 \mathrm{~g})\end{array}$ & 408 & 503.37 & 632 & $\begin{array}{l}\text { Rice }(210 \mathrm{~g}) \\
\text { Beef seaweed soup }(59 \mathrm{~g}) \\
\text { Kimchi }(40 \mathrm{~g}) \\
\text { Seasoned spinach }(86 \mathrm{~g}) \\
\text { Grilled croaker }(62 \mathrm{~g})\end{array}$ & 457 & 533.64 & 901 \\
\hline Lunch & $\begin{array}{l}\text { Brown rice }(210 \mathrm{~g}) \\
\text { Kimchi stew }(149 \mathrm{~g}) \\
\text { Radish kimchi }(50 \mathrm{~g}) \\
\text { Seasoned mung bean sprout }(38 \mathrm{~g}) \\
\text { Radish water kimchi }(250 \mathrm{~g})\end{array}$ & 697 & 905.71 & 841 & $\begin{array}{l}\text { Brown rice }(210 \mathrm{~g}) \\
\text { Enoki tofu doenjang soup }(128 \mathrm{~g}) \\
\text { Steamed egg }(68 \mathrm{~g}) \\
\text { Braised shishito pepper }(111 \mathrm{~g}) \\
\text { Seasoned bean sprout }(78 \mathrm{~g})\end{array}$ & 594 & $1,033.96$ & 952 \\
\hline Dinner & $\begin{array}{l}\text { Barley rice }(210 \mathrm{~g}) \\
\text { Korean wild chive doenjang jjigae }(116 \mathrm{~g}) \\
\text { Whole radish kimchi }(35 \mathrm{~g}) \\
\text { Perilla leave pickle }(2 \mathrm{~g}) \\
\text { Japchae with shiitake mushroom }(81 \mathrm{~g})\end{array}$ & 524.6 & $1,169.4$ & 1,176 & $\begin{array}{l}\text { Barley rice }(210 \mathrm{~g}) \\
\text { Napa cabbage soup }(100 \mathrm{~g}) \\
\text { Spicy stir fried pork }(157 \mathrm{~g}) \\
\text { Lettuce fresh kimchi }(91 \mathrm{~g}) \\
\text { Seasoned eggplant }(68 \mathrm{~g})\end{array}$ & 531.8 & $1,035.52$ & 1,416 \\
\hline Total & - & $1,629.6$ & $2,578.48$ & 2,649 & - & $1,582.8$ & $2,608.47$ & 3,269 \\
\hline
\end{tabular}


and II' published by the National Academy of Agricultural Science under the RDA, there is no specific nutritional intake level for each amino acid. Therefore, only the categories of total amino acids, essential amino acids, and non-essential amino acids were considered.

In Table 2, vitamin $A$, vitamin $\mathrm{D}$, vitamin $\mathrm{B}_{12}$, calcium $(\mathrm{Ca}), \mathrm{Fe}$, magnesium $(\mathrm{Mg})$, phosphorus $(\mathrm{P})$, potassium $(\mathrm{K})$, sodium $(\mathrm{Na}), \mathrm{Zn}$, and folic acid were selected as micronutrients, all of which have recommended indicators. Their levels differed between the SMP and VMP. The levels of vitamins $\mathrm{A}, \mathrm{D}$, and $\mathrm{B}_{12}$ in the VMP were $0 \mu \mathrm{g}$. The recommended intake of each nutrient was $800 \mu \mathrm{g} / \mathrm{day}$ for vitamin $\mathrm{A}$ (retinol), $2.4 \mu \mathrm{g} /$ day for vitamin $\mathrm{B}_{12}, 800 \mathrm{mg} /$ day for $\mathrm{Ca}, 10 \mathrm{mg} /$ day for $\mathrm{Fe}$ and $\mathrm{Zn}, 350$ $\mathrm{mg} /$ day for $\mathrm{Mg}, 700 \mathrm{mg} /$ day for $\mathrm{P}$, and $400 \mu \mathrm{g}$ dietary folate equivalent/day for folic acid. The intakes of $\mathrm{Na}$ and $\mathrm{K}$ were 2,000 and 3,500 mg/day, respectively, with these values based on sufficient intake and not recommended values $[14,18]$

\section{GHGs quantification method for the SMP and VMP}

Table 3 shows the carbon footprint of food items from The Foundation of Agriculture Technology Commercialization and Transfer (FACT), which were used to calculate GHG emissions for the VMP and SMP. In the FACT report, Toram Inc. used life cycle inventory database from Eco-invent (Switzerland) and LCA food (Denmark) to utilize the Life Cycle Assessment (LCA). There were four stages in the calculation of GHG emissions for food. First, food production was classified into three steps: (1) a preparation step, including seeding, herbicide and fertilizer use, water consumption, and use of fossil fuels; (2) a production step that could use organic or conventional methods; (3) a processing step, which involved consideration of additives, processing, packaging, transport, and storage. Second, there was a transport stage, in which land transportation by truck was selected. The average transportation distance was taken as $180 \mathrm{~km}$ from production site to the sale site [19]. Third, there was a consumption stage, which involved the use of liquefied natural gas, and a standard cooking time and heating power were selected to calculate GHG emissions. Finally, there was a disposal stage, but this was excluded because the resulting values were unreliable and accounted for only a small share of the total emissions [20].

With the meal plans and GHG emissions data, GHG emissions per nutritional value, especially calories (kcal) and proteins (g), were calculated. GHG emissions and nutritional value of the SMP was set as a standard to compare against the VMP.

Table 2. The recommended nutritional indicators per day for aged 19 to 29 adult men

\begin{tabular}{lcc}
\hline \multicolumn{1}{c}{ Nutrient } & Recommended nutritional indicators & Unit \\
\hline Protein & 65 & $\mathrm{~g} / \mathrm{day}$ \\
Vitamin A & 800 & $\mu \mathrm{g} / \mathrm{day}$ \\
Vitamin D & $100-200$ & $\mu \mathrm{g} / \mathrm{day}$ \\
Vitamin $\mathrm{B}_{12}$ & 2.4 & $\mu \mathrm{g} / \mathrm{day}$ \\
$\mathrm{Ca}$ & 800 & $\mathrm{mg} / \mathrm{day}$ \\
$\mathrm{Fe}$ & 10 & $\mathrm{mg} / \mathrm{day}$ \\
$\mathrm{Mg}$ & 350 & $\mathrm{mg} / \mathrm{day}$ \\
$\mathrm{P}$ & 700 & $\mathrm{mg} / \mathrm{day}$ \\
$\mathrm{K}$ & 3,500 & $\mathrm{mg} / \mathrm{day}$ \\
$\mathrm{Na}$ & 2,000 & $\mathrm{mg} / \mathrm{day}$ \\
$\mathrm{Zn}$ & 10 & $\mathrm{mg} / \mathrm{day}$ \\
Folic acid & 400 & $\mu \mathrm{d} / \mathrm{day}$ \\
\hline
\end{tabular}

Adapted from the 'Dietary Reference Intakes For Koreans 2015' (DRI 2015) [14]. 
Table 3. The carbon footprint for each food item from production to cooking

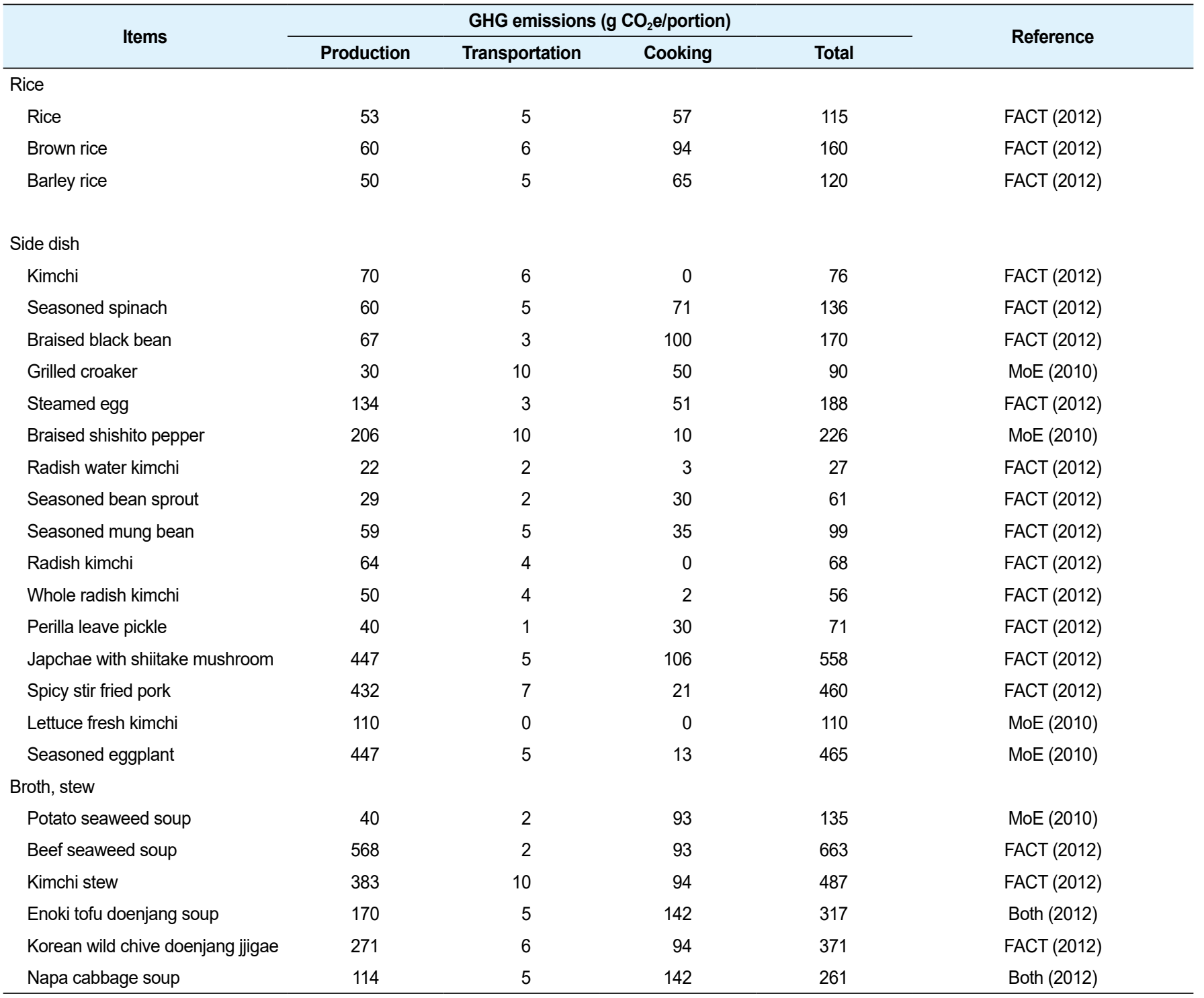

Adapted from Toram \& Ministry of Environment (MoE) and The Foundation of Agriculture Technology Commercialization and Transfer (FACT) [19,20].

$\mathrm{GHG}$, greenhouse gas; $\mathrm{CO}_{2} \mathrm{e}, \mathrm{CO}_{2}$ equivalent.

\section{RESULTS AND DISCUSSION}

As shown in Fig. 2, the SMP was used as the standard to compare the relative GHG emissions per calorie with the VMP GHG emissions per calorie. The SMP GHG emissions per calorie were $1.253 \mathrm{~g} \mathrm{CO}_{2} \mathrm{e} / \mathrm{kcal}$, while for the VMP the corresponding value was $1.027 \mathrm{~g} \mathrm{CO}_{2} \mathrm{e} / \mathrm{kcal}$. Therefore, the VMP emissions per calorie were $18 \%$ lower than the SMP GHG emissions per calorie. GHG emissions from the SMP, which contained animal products, were greater than those from the VMP, but there was insufficient meal plan data to determine if the difference was statistically significant [10]. Table 4 shows the levels of proteins and amino acids in the diets. Based on these values, the GHG emissions per protein $\left(\mathrm{g} \mathrm{CO}_{2} \mathrm{e} / \mathrm{g}\right)$ in the SMP were calculated to be $31.75 \mathrm{~g} \mathrm{CO}_{2} \mathrm{e} / \mathrm{g}$, while for the VMP the corresponding value was $40.85 \mathrm{~g} \mathrm{CO}_{2} \mathrm{e} / \mathrm{g}$. The $\mathrm{GHG}$ emissions per essential amino acid $\left(\mathrm{g} \mathrm{CO}_{2} \mathrm{e} / \mathrm{mg}\right)$ in the SMP were $0.06 \mathrm{~g} \mathrm{CO}_{2} \mathrm{e} / \mathrm{mg}$, while for the VMP the corresponding 


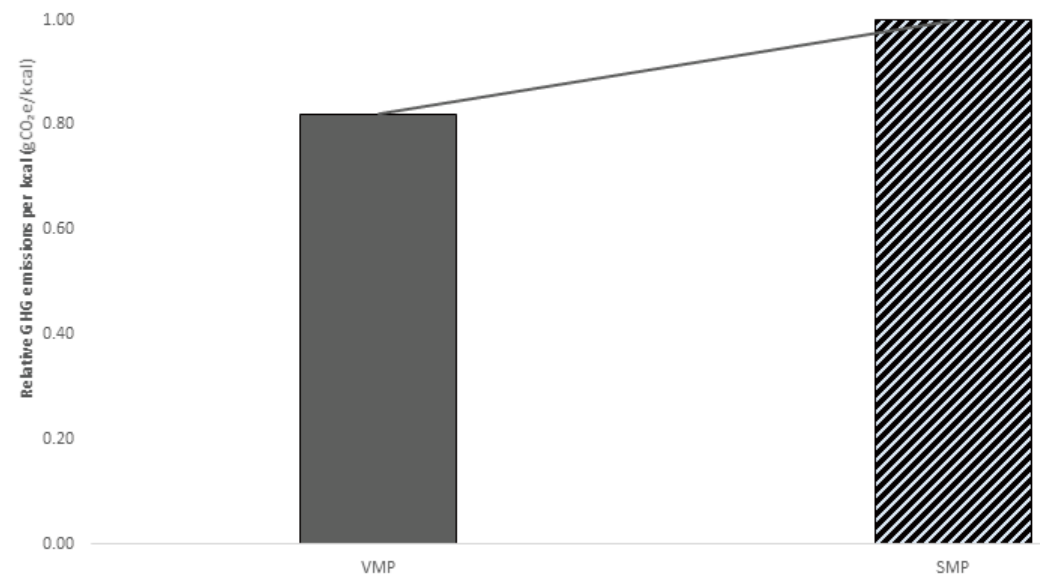

Fig. 2. Comparing the SMP GHG emissions per calories $\left(\mathrm{g} \mathrm{CO}_{2} \mathrm{e} / \mathrm{kcal}\right)$ with VMP GHG emissions per calories ( $\left(\mathrm{g} \mathrm{CO}_{2} \mathrm{e} / \mathbf{k c a l}\right)$. SMP, suggested meal plan; $\mathrm{GHG}$, greenhouse gas; VMP, vegan meal plan.

Table 4. Greenhouse gas (GHG) emissions per protein ( $\mathrm{g} \mathrm{CO}_{2}$ equivalent/g) and GHG emissions per amino acid ( $\mathrm{g} \mathrm{CO}_{2}$ equivalent $/ \mathrm{mg}$ ) in a vegan meal plan (VMP) and suggested meal plan (SMP)

\begin{tabular}{lrr}
\hline & VMP & SMP \\
\hline GHG emissions per protein $\left(\mathrm{g} \mathrm{CO}_{2} \mathrm{e} / \mathrm{g}\right)$ & 40.85 & 31.75 \\
$\mathrm{GHG}$ emissions per amino acid $\left(\mathrm{g} \mathrm{CO}_{2} \mathrm{e} / \mathrm{mg}\right)$ & 0.12 & 0.06 \\
\hline
\end{tabular}

$\mathrm{CO}_{2} \mathrm{e}, \mathrm{CO}_{2}$ equivalent.

value was $0.12 \mathrm{~g} \mathrm{CO}_{2} \mathrm{e} / \mathrm{mg}$, as shown in Table 4. The VMP emitted more GHGs under both conditions, but the specific origin of the protein source and essential amino acids should be considered $[10,21]$. For example, the sources of proteins and amino acids from animal products include eggs, beef, pork, chicken, fish, and milk. The sources of proteins and amino acids from plants include soybeans, tofu, barley, and brown rice. However, plant-based proteins or amino acids are incomplete sources and need to be mixed with animal products or consumed in large amounts to meet the recommended intake, otherwise supplements should be taken to meet the shortfall [14]. These results indicated that even when a meal plan includes some animal products, its GHG emissions may not be higher than a plant-based meal plan. Table 5 shows that the amount of vitamins $A, D$, and $\mathrm{B}_{12}$ in a VMP diet is $0 \mu \mathrm{g}$, whereas in an SMP diet the respective amounts are 83.12,17.62, and $4.48 \mu \mathrm{g}$, indicating that these vitamins should be obtained by taking supplements when following the VMP

Table 5. Micronutrients (vitamins A, D, and $B_{12}$ ) in a vegan meal plan (VMP) and suggested meal plan (SMP)

\begin{tabular}{|c|c|c|c|c|c|c|}
\hline \multirow{2}{*}{ Meal } & \multicolumn{2}{|c|}{ Vitamin A } & \multicolumn{2}{|c|}{ Vitamin D } & \multicolumn{2}{|c|}{ Vitamin $B_{12}$} \\
\hline & VMP & SMP & VMP & SMP & VMP & SMP \\
\hline Breakfast $(\mu \mathrm{g})$ & 0.00 & 0.60 & 0.00 & 5.05 & 0.00 & 3.26 \\
\hline Lunch $(\mu \mathrm{g})$ & 0.00 & 81.60 & 0.00 & 12.56 & 0.00 & 1.00 \\
\hline Dinner $(\mu \mathrm{g})$ & 0.00 & 0.92 & 0.00 & 0.00 & 0.00 & 0.23 \\
\hline Total $(\mu \mathrm{g})$ & 0.00 & 83.12 & 0.00 & 17.61 & 0.00 & 4.48 \\
\hline
\end{tabular}

Adapted from the 'Korean Food Composition Tables I and II, $9^{\text {th }}$ ed.' $[16,17]$. 
Table 6. Macronutrients (protein, total amino acids, essential amino acids, and non-essential amino acids) in the vegan meal plan (VMP) and suggested meal plan (SMP)

\begin{tabular}{|c|c|c|c|c|c|c|c|c|}
\hline \multirow{2}{*}{$\begin{array}{c}\text { Nutrient } \\
\text { components }\end{array}$} & \multicolumn{2}{|c|}{ Protein $(g)$} & \multicolumn{2}{|c|}{ Total amino acid (mg) } & \multicolumn{2}{|c|}{ Essential amino acid (mg) } & \multicolumn{2}{|c|}{ Non-essential amino acid (mg) } \\
\hline & VMP & SMP & VMP & SMP & VMP & SMP & VMP & SMP \\
\hline Breakfast & 18.68 & 32.31 & $6,897.28$ & $20,297.68$ & $3,077.95$ & $9,468.57$ & $3,819.33$ & $10,829.11$ \\
\hline Lunch & 22.15 & 35.40 & $6,541.28$ & $18,869.00$ & $2,850.16$ & $8,761.83$ & $3,691.12$ & $10,107.17$ \\
\hline Dinner & 24.02 & 35.25 & $8,649.70$ & $19,329.72$ & $3,751.36$ & $9,167.93$ & $4,898.34$ & $10,168.94$ \\
\hline Total & 64.85 & 102.95 & $32,759.11$ & $69,691.38$ & $14,359.53$ & $32,293.70$ & $18,399.58$ & $37,404.83$ \\
\hline
\end{tabular}

Adapted from the ' 9 th Korean Food Composition Tables I and II'.

diet. GHG emissions data for vitamin or amino acid supplements were not available and therefore it was not possible to make a comparison between diets that included supplements.

From a health perspective, a vitamin A deficiency can lead to abnormal development and growth in humans, particularly in the immune system [17]. Vitamin D helps the body absorb $\mathrm{Ca}, \mathrm{Mg}$, and $\mathrm{P}$, which is important for normal bone development and maintenance. With a vitamin $\mathrm{D}$ deficiency, rickets and osteoporosis can occur in children and adults, respectively [18,22,23]. Vitamin $\mathrm{B}_{12}$ deficiency can lead to pernicious anemia and neurological disorders, such as delayed brain growth, spinal degeneration, and poor intellectual development [17,18,24,25].

Table 6 shows that the SMP provided 2.13 times more amino acids than the VMP, with 2.25 times more essential amino acids and 2.03 times more non-essential amino acids. A long-term VMP diet would likely result in a deficiency of essential and non-essential amino acids. This would weaken the immune system and increase the likelihood of developing various diseases. Among the essential amino acids, methionine deficiency can affect body weight and eating patterns [14,21].

Fig. 3 compares the micronutrient total intake with the recommended intake for the two meal plans. For both meal plans, $\mathrm{Ca}$ and $\mathrm{Zn}$ intake did not reach the recommended amount. If this condition persists, there is a risk that bone density will decrease, leading to osteoporosis. In addition, a continuous low intake of $\mathrm{Ca}$ may result in exposure to various health conditions, such as cardiovascular disease, degenerative joint disease, and neurodegenerative disease [14,26]. Zn deficiency is related to growth disorders, loss of appetite, diarrhea, vomiting, and inflammation. Excessive $\mathrm{Zn}$ uptake prevents the absorption of other micronutrients and weakens the immune system [14,26]. The other micronutrients exceeded the recommended intake in both the VMP and SMP.

\section{CONCLUSION}

When comparing the SMP and VMP in terms of the quantification of GHG emissions, the SMP resulted in higher GHG emissions than the VMP, but this could change depending on the type of food selected in the diet. Further studies are required to investigate the variation in GHG emissions between different meal plans based on the different amounts of proteins or amino acids in the diets, and by considering daily meat intake per person.

In terms of health concerns, the SMP contains large amounts of amino acids, vitamin D, and vitamin $\mathrm{B}_{12}$, but a VMP diet cannot deliver the recommended intake. It could possibly lead to amino acid, vitamin $D$, or vitamin $B_{12}$ deficiency, with a need to consume multivitamin supplements or amino acid additives. It is therefore necessary to consider if the production of supplements emits GHGs.

There is a need to establish LCA data related to various supplements, which would enable a comparison of GHG emissions between individuals that consume supplements with a VMP and those eating an SMP, which might lead to an increase in GHG emissions by vegans. LCA data are 


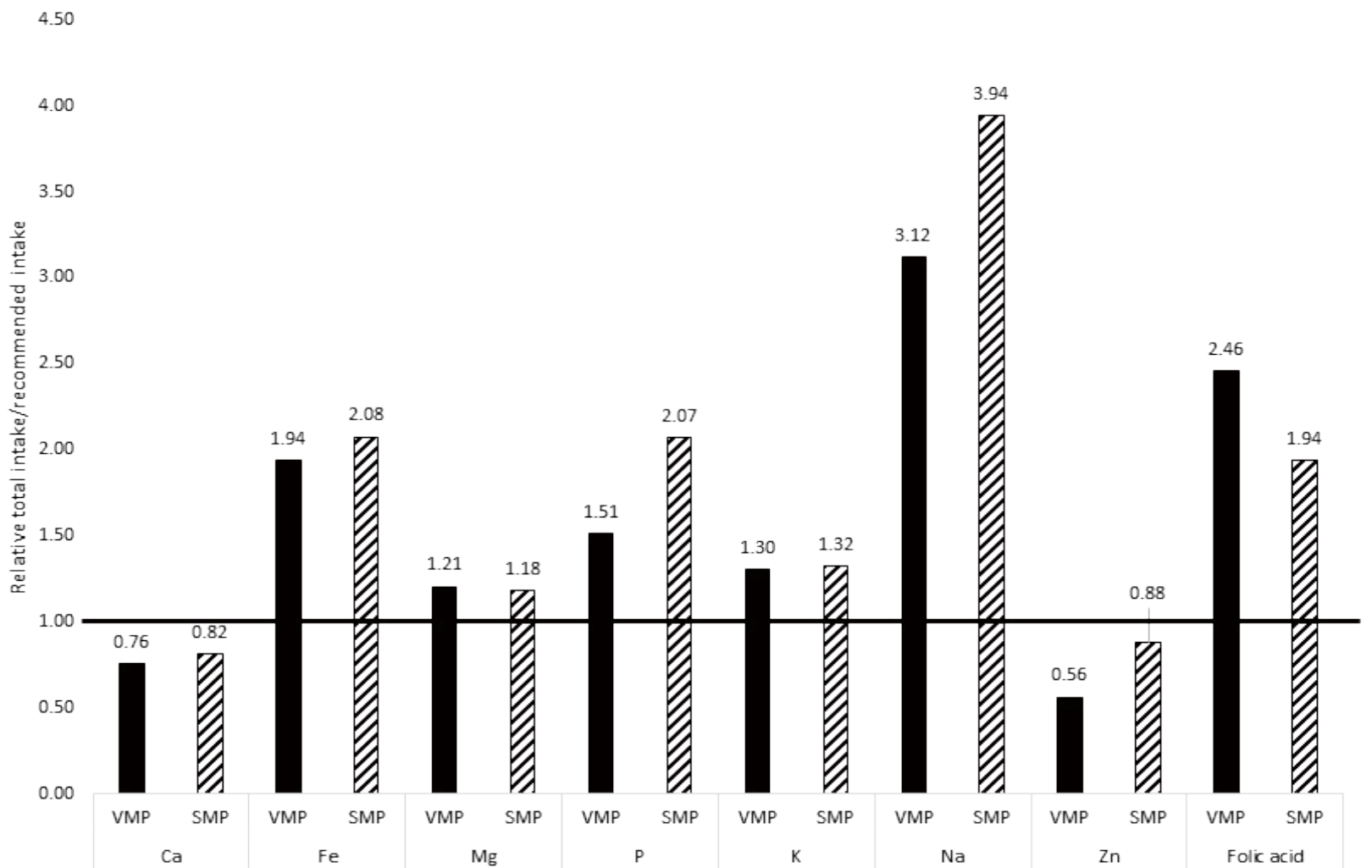

Fig. 3. Comparing micronutrient total intake/recommended intake for $\mathrm{Ca}, \mathrm{Fe}, \mathrm{Mg}, \mathrm{P}, \mathrm{K}, \mathrm{Na}$, and folic acid between VMP and SMP. VMP, vegan meal plan; SMP, suggested meal plan.

not currently available for all ingredients, and for the more eco-friendly meal plans further research is needed to establish a specific database for additional meals. Plus, for the credibility issues, further research need to be conducted about the women of the same age. Such a study could provide reasons why animal products should be consumed. Because of the growing interest in other environmental impacts, such as nitrogen and water footprints, these issues should be examined in the near future.

\section{REFERENCES}

1. Tilman D, Clark M. Global diets link environmental sustainability and human health. Nature. 2014;515:518-22.

2. Murphy SP, Allen LH. Nutritional importance of animal source foods. J Nutr. 2003;133:3932S-35S.

3. Craig WJ. Health effects of vegan diets. Am J Clin Nutr. 2009;89:1627S-33S.

4. Scarborough P, Appleby PN, Mizdrak A, Briggs ADM, Travis RC, Bradbury KE, et al. Dietary greenhouse gas emissions of meat-eaters, fish-eaters, vegetarians and vegans in the UK. Clim Change. 2014;125;179-92.

5. Godfray HCJ, Aveyard P, Garnett T, Hall JW, Key TJ, Lorimer J, et al. Meat consumption, health, and the environment. Science 2018;361:243.

6. Intergovernmental Panel on Climate Change [IPCC]. Climate change 2014: mitigation of climate change. Contribution of working group III to the fifth assessment report of the Intergov- 
ernmental Panel on Climate Change [Edenhofer O, Pichs-Madruga R, Sokona Y, Farahani E, Kadner S, Seyboth K, et al., editors]. Cambridge, UK: Cambridge University Press; 2014.

7. Food and Agriculture Organization of the United Nations [FAO]. Climate change in livestock. http://www.fao.org/climate-change/our-work/areas-of-work/livestock/en/. Accessed 25 Sept 2019.

8. Smetana S, Mathys A, Knoch A, Heinz V. Meat alternatives: life cycle assessment of most known meat substitutes. Int J Life Cycle Assess. 2015;20:1254-67.

9. Klurfeld DM. What is the role of meat in a healthy diet? Anim Front. 2018;8:5-10.

10. Gonzalez AD, Frostell B, Carlsson-Kanyama A. Protein efficiency per unit energy and per unit greenhouse gas emissions: potential contribution of diet choices to climate change mitigation. Food Policy. 2011;36:562-70.

11. Springmann M, Wiebe K, Mason-D'Croz D, Sulser TB, Rayner M, Scarborough. Health and nutritional aspects of sustainable diet strategies and their association with environmental impacts: a global modelling analysis with country-level detail. Lancet Planet Health. 2018; 2:e451-61.

12. Steen-Olsen K, Hertwich EG. Life cycle assessment as a means to identify the most effective action for sustainable consumption. In: Reisch LA, Thogersen J, editors. Handbook of research on sustainable consumption. Northampton, MA: Edward Elgar; 2015. p. 131-44.

13. McMichael AJ, Powles JW, Butler CD, Uauy R. Food, livestock production, energy, climate change, and health. Lancet. 2007;370:1253-63.

14. Ministry of Health \& Welfare. 2015. Dietary reference intakes for Koreans 2015. Seoul: The Korean Nutrition Society; 2015.

15. National Institute of Agricultural Sciences: Meal plan menu. http://koreanfood.rda.go.kr/kfi/ mgnmenusrchMenuquery/list. Accessed 25 Jun 2018.

16. The Rural Development Administration. Korean food composition table I. 9th ed.2016. https://koreanfood.rda.go.kr:2360/kfi/fct/fctIntro/list?menuId=PS03562. Accessed 30 Jun 2019.

17. The Rural Development Administration. Korean food composition table II. 9th ed. 2016. https://koreanfood.rda.go.kr:2360/kfi/fct/fctIntro/list?menuId=PS03562. Accessed 30 Jun 2019.

18. Pilz S, Trummer C, Pandis M, Schwetz, Aberer F, Grubler M, et al. Vitamin D: current guidelines and future outlook. Anticancer Res. 2018;38:1145-51.

19. Toram, Ministry of Environment [MOE]. Research of energy consumption and calculation of GHG emissions from food. Gwachoen, Korea: Ministry of Environment; 2010. http://www. prism.go.kr/homepage/entire/retrieveEntireDetail.do;jsessionid=C522AA26D52926E04DC20F694BF9A5C0.node02?cond_research_name=\&cond_research_start_date $=\&$ cond research_end_date=\&research_id=1480000-201100468\&pageIndex=1462\&leftMenuLevel=160. Accessed 16 Jan 2020.

20. The Foundation of Agriculture Technology Commercialization and Transfer [FACT]. Building the database for food's footprint. 2012. http://www.smartgreenfood.org/jsp/front/story/ story03_1.jsp. Accessed 16 Jan 2020.

21. Joe Millward D. Human amino acid requirements. J Nutr. 1997;127:1842-6.

22. Chan J, Jaceldo-Siegl K, Fraser GE. Serum 25-hydroxyvitamin D status of vegetarians, partial vegetarians, and nonvegetarians: the adventist health study-2. Am J Clin Nutr. 2009;89:1686S-92S.

23. Aparna P, Muthathal S, Nongkynrih B, Gupta SK. Vitamin D deficiency in India. J Family Med Prim Care 2018;7:324-30. 
24. Weaver CM. Should dairy be recommended as part of a healthy vegetarian diet? Point. Am J Clin Nutr. 2009;89:1634S-7S.

25. Elmadfa I, Singer I. Vitamin B-12 and homocysteine status among vegetarians: a global perspective. Am J Clin Nutr. 2009;89:1693S-8S.

26. Kumssa DB, Joy EJM, Ander EL, Watts MJ, Young SD, Walker S, et al. Dietary calcium and zinc deficiency risks are decreasing but remain prevalent. Sci Rep. 2015;5:10974. 